\title{
Twolined Spittlebugs in Turfgrass 1
}

\section{E. Short, E. A. Buss, and L. Williams ${ }^{2}$}

Spittlebugs are present throughout the entire state, but they are more abundant in northern and northwestern Florida. They attack all turfgrass species, but centipedegrass is the most susceptible. Adults also feed on ornamental plants, especially hollies (Ilex cassine or I. opaca).

\section{Biology and Behavior}

Adult twolined spittlebugs, Prosapia bicincta (Say) (Figure 1), are black with red eyes and legs and have two orange stripes across their wings. They are about $1 / 4$ inch long. The nymphs are yellow or creamy in color with a brown head (Figure 2). They are surrounded by a mass of white frothy spittle (Figure 3) that they excrete for protection. Both adults and nymphs suck juices from the grass with their piercing-sucking mouthparts. But, damage (Figure 4) is caused primarily by the adults through the injection of phytotoxic salivary substances. Adults are most active in early morning and hide near the soil surface during the heat of the day.

There are usually two to three generations per year. There are four nymphal instars and the life cycle requires about 2 1/2 months. Eggs are laid at the base of the grass in the thatch, in hollow grass stems,

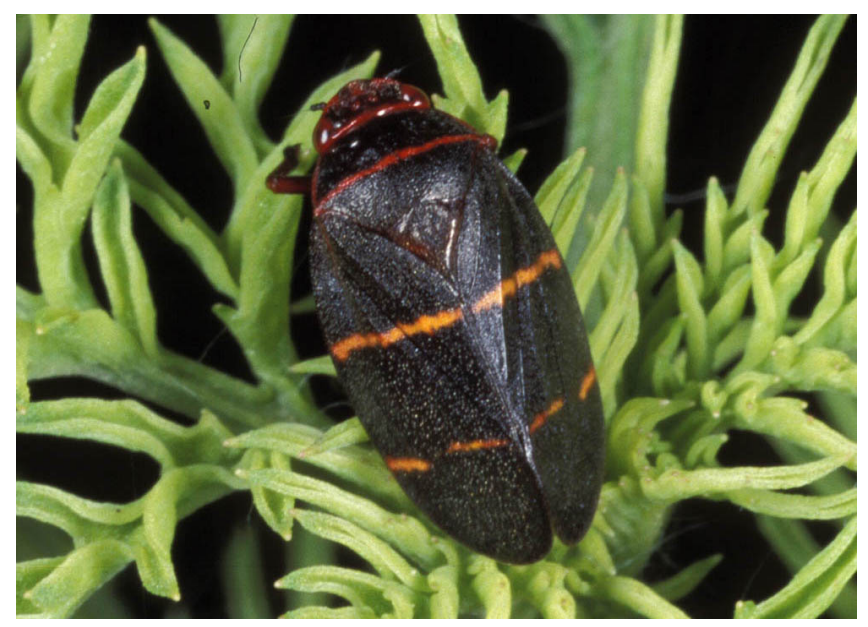

Figure 1. Twolined spittlebug adult. Credits: Lyle Buss, University of Florida

or behind the leaf sheaths. Eggs laid by the second generation overwinter and hatch the following spring, usually from late March to late April. First generation adults are abundant in June. The adult population may peak again in August or September.

\section{Detecting Infestations}

Spittlebug feeding causes a purple and/or white stripe to run along the grass blades of infested turfgrass, especially centipedegrass. In heavy infestations, the turf wilts and the tips turn yellow,

1. This document is ENY-334, one of a series of the Department of Entomology and Nematology, Florida Cooperative Extension Service, Institute of Food and Agricultural Sciences, University of Florida. Date first printed October 1993. Revised: September 2005. Please visit the EDIS Website at http://edis.ifas.ufl.edu.

2. D. E. Short, emeritus professor, E. A. Buss, assistant professor, Entomology and Nematology Department, Gainesville, and L. Williams, Okaloosa County Extension Agent, Cooperative Extension Service, Institute of Food and Agricultural Sciences, University of Florida.

The Institute of Food and Agricultural Sciences (IFAS) is an Equal Opportunity Institution authorized to provide research, educational information and other services only to individuals and institutions that function with non-discrimination with respect to race, creed, color, religion, age, disability, sex, sexual orientation, marital status, national origin, political opinions or affiliations. U.S. Department of Agriculture, Cooperative Extension Service, University of Florida, IFAS, Florida A. \& M. University Cooperative Extension Program, and Boards of County Commissioners Cooperating. Larry Arrington, Dean 


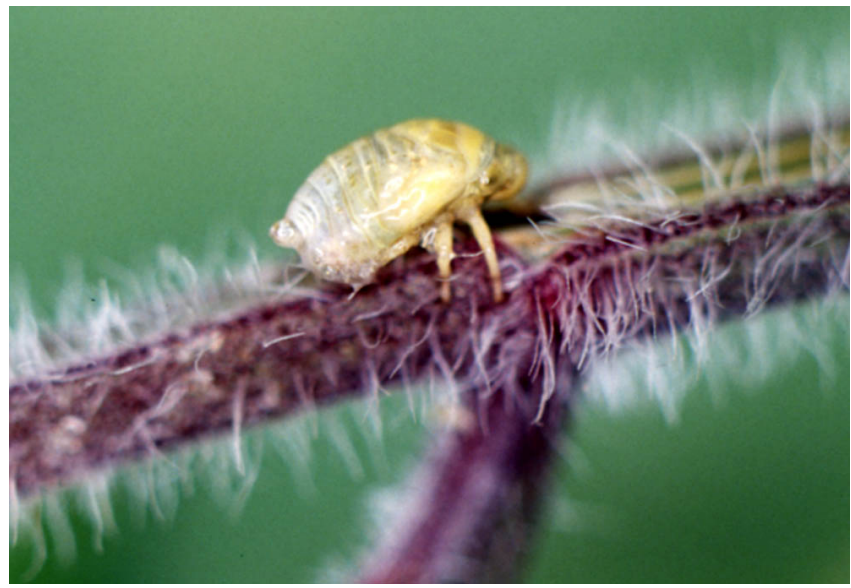

Figure 2. Exposed spittlebug nymph. Credits: J. L. Castner, University of Florida

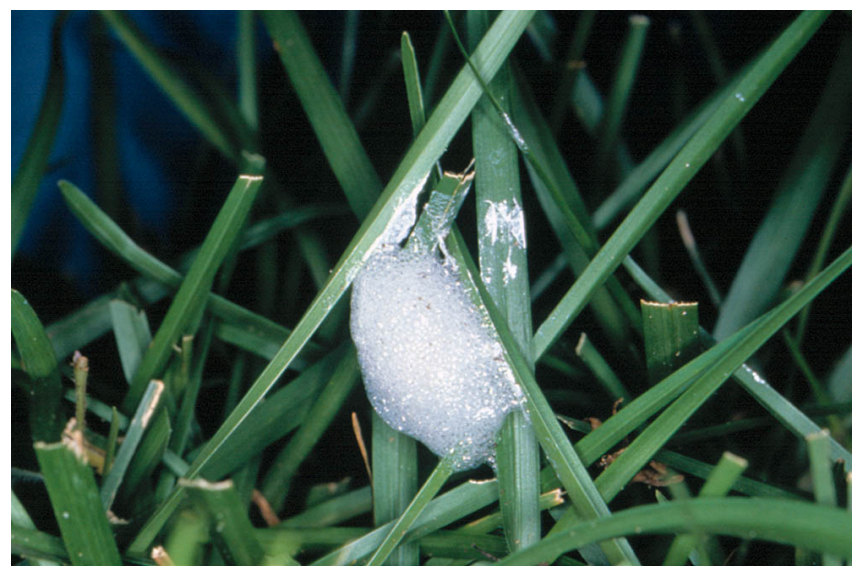

Figure 3. Spittle mass. Credits: E. A. Buss, University of Florida

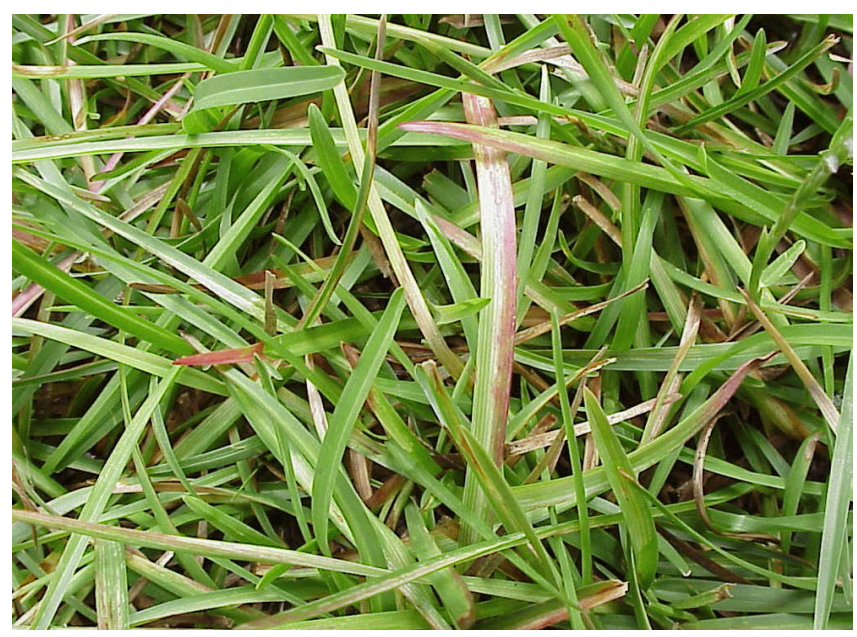

Figure 4. Spittlebug damage on centipedegrass. Credits: Larry Williams

eventually brown, and then curl. In St.

Augustinegrass, spittlebug injury resembles that of chinch bugs. However, unlike chinch bug injury, which tends to occur in sunny areas, spittlebug injury usually appears in shady areas.
Most spittle masses occur near the soil surface or in the thatch, so they are not readily visible. However, some dried spittle masses may appear on grass blades during adult emergence. High moisture conditions favor their development. Typically, spittlebug numbers are higher during years with more spring and summer rainfall and under high humidity conditions. Excess thatch also favors their development.

\section{Cultural Control}

Follow approved practices regarding mowing, fertilization and irrigation to reduce thatch buildup. If a thatch problem exists, dethatching should reduce spittlebug problems. Avoid over-irrigating turf to minimize infestation. Spittlebugs will not survive drought conditions.

If possible, plant a more resistant turfgrass species or cultivar (e.g., St. Augustinegrass, seashore paspalum, zoysiagrass) and avoid centipedegrass.

\section{Biological Control}

None of the specific natural enemies of the twolined spittlebug have been identified.

\section{Chemical Control}

To minimize turf injury, chemical control may be required when spittlebug populations are heavy. To improve control, mow and dispose of clippings before an insecticide is applied. Irrigating before treatment will also aid in control, or increase the amount of water used in the spray solution. Granular insecticides may not be as effective as liquid formulations. It is best to monitor or apply insecticides late in the day when nymphs are higher on the plants than during the hot midday. Adult spittlebugs are usually more successfully controlled than nymphs. The nymphs are protected by the spittle masses. 
Table 1. Professional and non-professional insecticides registered in Florida for use against spittlebugs in turfgrass.

\begin{tabular}{|c|c|c|c|}
\hline Chemical Name & Florida Registered Products & Chemical Class & Signal Word \\
\hline \multirow[t]{2}{*}{ Bifenthrin } & Onyx & \multirow[t]{2}{*}{ Pyrethroid } & Warning \\
\hline & Talstar One & & Caution \\
\hline Carbaryl & Sevin SL & Carbamate & Caution \\
\hline \multirow[t]{4}{*}{ Cyfluthrin } & Tempo 20 WP & \multirow[t]{4}{*}{ Pyrethroid } & Caution \\
\hline & Tempo SC Ultra & & Caution \\
\hline & Tempo Ultra SP & & Caution \\
\hline & Tempo Ultra WSP & & Caution \\
\hline \multirow[t]{2}{*}{ Imidacloprid } & Merit 75 WP/WSP & \multirow[t]{2}{*}{ Chloronicotinyl } & Caution \\
\hline & $\begin{array}{l}\text { Bayer Advanced Season Long Grub } \\
\text { Control }\end{array}$ & & Caution \\
\hline Lambda-cyhalothrin & Scimitar CS & Pyrethroid & Caution \\
\hline \multirow[t]{2}{*}{ Permethrin } & Astro & \multirow[t]{2}{*}{ Pyrethroid } & Caution \\
\hline & $\begin{array}{l}\text { Permethrin Pro Termite-Turf } \\
\text { Ornamental }\end{array}$ & & Caution \\
\hline
\end{tabular}

Table 2. Homeowner insecticides registered in Florida for use against spittlebugs in turfgrass.

\begin{tabular}{||l|l|l|l||}
\hline \multicolumn{1}{|c|}{ Chemical Name } & \multicolumn{1}{|c||}{ Florida Registered Products } & \multicolumn{1}{|c|}{ Chemical Class } & Signal Word \\
\hline Bifenthrin & $\begin{array}{l}\text { Scott's Max Guard Insect Protection } \\
\text { with Turf Builder Fertilizer }\end{array}$ & Pyrethroid & Warning \\
\hline Carbaryl & $\begin{array}{l}\text { Garden Tech Sevin Concentrate } \\
\text { Bug Killer }\end{array}$ & Carbamate & Caution \\
\hline Cyfluthrin & $\begin{array}{l}\text { Bayer Advanced Lawn and Garden } \\
\text { Multi-Insect Killer }\end{array}$ & Pyrethroid & Caution \\
\hline Deltamethrin & $\begin{array}{l}\text { Southern Ag Mole Cricket and } \\
\text { Chinch Bug Lawn Insect Control }\end{array}$ & Pyrethroid & Caution \\
\hline Lambda-cyhalothrin & Spectracide Triazicide & Pyrethroid & Caution \\
\hline Permethrin & Real Kill Multi-Purpose Insect Killer & Pyrethroid & Caution \\
\hline \hline
\end{tabular}

